\title{
OPTIMASI FORMULA GEL SERBUK DAGING LIMBAH TOMAT (Licopersicum asculentum Mill) DAN UJI AKTIVITAS TERHADAP LAMA PENYEMBUHAN LUKA EKSISI PADA KELINCI
}

\author{
Dzun Haryadi Ittiqo, Yuli Fitriana \\ Program Studi D3 Farmasi, Universitas Muhammadiyah Mataram, \\ dzun.haryadi@gmail.com
}

\section{INFO ARTIKEL}

\section{Riwayat Artikel:}

Diterima : 18-11- 2017

Disetujui : 01-12 - 2017

\section{Kata Kunci:}

Gel

Limbah tomat

D-optimal design

Luka eksisi

\section{A. LATAR BELAKANG}

Salah satu jenis luka adalah luka eksisi, luka eksisi adalah luka yang diakibatkan terpotongnya jaringan oleh goresan benda tajam. Prevalensi cedera luka terbuka di Indonesia tercatat sebesar $25,4 \%$ dan paling banyak di jumpai pada kelompok umur 25 sampai 34 tahun sebesar 32 \%. Tujuan utama penata laksanaan luka adalah untuk mencapai penyembuhan yang cepat dengan fungsi yang optimal dan hasil yang bagus. Umumnya penanganan luka dengan mencegah infeksi dan trauma selanjutnya (Priyandari and Maulidah 2015). 
Obat topikal sintesis yang umum digunakan pada luka eksisi adalah kompres iodium povidon atau nitrasargenti 0,5\% yang berperan sebagai bakteriostatik untuk semua kuman(Sjamsu 2005). Tetapi penggunaan iodium povidon dan nitras-argenti yang berlebihan dapat menimbulkan efek samping berupa dermatitis, bengkak, gatal dan rangsangan nyeri yang sangat pada daerah sekitar luka sehingga diperlukan alternatif obat alami yang lebih aman dan memiliki efektifitas yang sama dengan bahan sintetik .

Variasi tanaman sangat banyak di Alam yang dapat dimanfaatkan atau telah dimanfaatkan oleh Masyarakat, baik sebagai bahan makanan maupun sebagai bahan obat-obatan, salah satunya tanaman tomat. Tomat sebagai komuditi pertanian untuk keperluan rumah tangga apabila sudah matang akan mengandung air tidak kurang dari $95 \%$ sehingga kandungan tersebut menyebabkan tomat mudah membusuk atau mudah rusak secara fisik. Tomat yang rusak hanya dijadikan limbah yang tidak bermanfaat dan sering menimbukan masalah bagi lingkungan karena belum adanya upaya pengolahan menjadi produk yang bermanfaat (Sumardiono, Basri, and Pasonang Sihombing 2009).

Tomat mengandung mengandung beberapa senyawa kimia, dua diantaranya adalah saponin dan bioflavonoid (Suhartati 2015). Senyawa golongan plavonoid, saponin dan tannin telah dibuktikan secara pre klinis bisa mempercepat penyembuhan luka. Diantaranya Priandari dkk pada tahun 2015 meneliti tentang getah pohon jarak dengan kandungan plavonoid dibuat sediaan topikal ditujukan untuk mengetahui lama penyembuhan luka eksisi pada mencit. Disimpulkan bahwa rata-rata penyembuhan luka setelah diberi getah pohon jarak lebih cepat 7 hari dibandingkan dengan perawatan luka menggunakan $\mathrm{NaCl} 0,9 \%$ (Priyandari and Maulidah 2015).

Bentuk sediaan dengan rute topikal sangat disukai, salah satunya adalah gel. Sediaan gel mempunyai beberapa sifat yang disukai seperti alirannya yang tiksotropik, tidak lengket, mudah menyebar, mudah dibersihkan, kompatibel dengan beberapa eksipien dan larut dalam air (Soebagio and Rusdiana 2007). Untuk mendapatkan sediaan gel yang bermutu dengan kwalitas yang baik maka diperlukan optimasi formula dengan memperhatikan konsentrasi serta karakteristik bahan yang digunakan.

Kandungan bioflavonoid pada tomat dimungkinkan memiliki potensi yang sama dengan zat aktif lainnya yang telah dibuktikan secara pre klinis sebagai obat penyembuh luka terbuka maupun luka sayatan. Atas dasar itu dianggap penting melakukan penelitian tentang optimasi formula gel serbuk daging limbah tomat (Licopersicum asculentum Mill) dan uji aktivitas terhadap lama penyembuhan luka eksisi pada kelinci.

\section{B. METODE PENELITIAN}

\section{Desain Penelitian}

Penelitian ini menggunakan desain penelitian eksperimental yang merupakan penelitian laboratorium dengan metode D-Optimal.

\section{Tempat dan Waktu Penelitian}

Penelitian ini dilakukan pada bulan pebruarimaret tahun 2018 di Laboratorium Farmakognosi dan Teknologi Farmasi D3 Farmasi Universitas Muhammadiyah Mataram.

\section{Sampel Penelitian}

Serbuk daging daging limbah buah tomat yang diperoleh dari petani di desa dasan agung, kabar kecamatan sakra.

Kriteria Sampel :

a. Kriteria Inklusi : daging limbah buah tomat dan tomat pasca panen 2 hari.

b. Kriteria Eksklusi : daging buah tomat yang busuk.

\section{Variabel Penelitian}

Variabel bebas dalam penelitian ini adalah formulasi gel meliputi Na-CMC, gliserin, propilenglikol, aquadest dan konsentrasi serbuk daging limbah tomat. Variabel tergantung adalah $\mathrm{PH}$, daya sebar, daya lekat dan lama penyembuhan luka eksisi, sedangkan variabel terkendali yaitu kondisi percobaan yang meliputi suhu, waktu pencampuran dan lama pencampuran.

\section{Instrumen Penelitian}

a. Alat

Peralatan meliputi neraca analisis digital (Ohauss), alat-alat gelas, Mesh no 60, mortir dan stamper, Kertas PH, waterbath, kertas saring alat uji daya sebar, alat uji daya lekat.

b. Bahan

Bahan penelitian meliputi, daging tomat, pelarut berderajat teknis : etanol $90 \%, \mathrm{CMC}-\mathrm{Na}$, gliserin, propilenglikol, aquadest. Subjek uji penelitian ini adalah kelinci.

\section{Prosedur Penelitian}

\section{a. Persiapan Sampel Limbah Tomat}

Sampel diperoleh dari petani di desa dasan agung dibersihkan, dipisahkan dari bijinya. Bagian buah yang digunakan adalah daging buah tomat, kemudian dipotong kecil-kecil menjadi beberapa bagian. Dikeringkan dalam oven pada suhu 60$80^{\circ} \mathrm{C}$ sampai kering (Goeswin 2007).

b. Pembuatan Serbuk daging Limbah Buah Tomat :

Daging limbah tomat kering dihaluskan dengan blender selama 10 menit, selanjutnya di lakukan pengayakan dengan mesh no 60 untuk mendapatkan serbuk yang halus (Swastika and Mufrod 2013)

c. Optimasi formula gel serbuk daging limbah tomat.

Optimasi formula gel menggunkan metode D Optimal design dengan software design exspert versi 7.1.5. Komponen yang dioptimasi adalah formula standar gel basis natrium karboksimetil 
selulosa (Na-CMC), parameter atau respon yang dinilai adalah daya sebar dan Daya lekat.

d. Pembuatan Sediaan Gel

Bahan ditimbang sesuai dengan formula yang ada. Serbuk dilarutkan dalam sebagian air yang telah dipanaskan pada suhu $50^{\circ} \mathrm{C}$ ditambahkan NaCMC dan diaduk hingga homogen. Ditambahkan gliserin, propilenglikol dan sisa air dengan pengadukan secara kontinyu hingga terbentuk gel (Aponno 2014).

e. Uji mutu fisik formula gel serbuk daging limbah tomat.

1) Penentuan $\mathrm{PH}$

$100 \mathrm{mg}$ formula gel ditimbang dalam labu ukur $50 \mathrm{~mL}$ selanjutnya ditambahkan aquadest sampai $50 \mathrm{~mL}$ (konsentrasi o,2\%). $\mathrm{PH}$ gel dicatat dengan $\mathrm{PH}$ meter, $\mathrm{PH}$ meter dibiarkan kontak dengan gel selama 1 menit. Percobaan ini untuk memeriksa netralitas gel antar batch yang berbeda(Chaudhary et al. 2011)

2) Uji daya sebar

Setengah gram formula gel diletakkan di pusat antara 2 lempeng gelas, dimana lempeng sebelah atas ditimbang terlebih dahulu kemudian diletakkan diatas gel dan dibiarkan selama 1 menit. Diatasnya diberi beban $150 \mathrm{~g}$, dibiarkan 1 menit dan ukur diameter sebarnya. Pengamatan dilakukan setiap mnggu selama 4 minggu(Purwanto, Mufrod, and NSP 2015)

3) Uji Daya Lekat

$1 \mathrm{~g}$ gel dioleskan pada sebuah plat kaca. Plat kaca yang kedua ditempelkan sampai kedua plat kaca menyatu. Kemudian ditekan dengan beban seberat $1 \mathrm{~kg}$ selama 5 menit, lalu beban dilepas. Plat kaca diberi beban pelepasan 80 g. Dicatat waktu hingga kedua plat saling lepas(Kurniawati, Hapsari, and Hartanti 2010)

f. Uji aktivitas lama penyembuhan luka formula gel optimum.

1) Penyiapan hewan uji dan pembuatan luka Hewan uji yang digunakan adalah kelinci sebanyak 3 ekor, Punggung kelinci dicukur bulunya sampai licin kemudian dibersihkan dengan alkohol 70\%. Area pada punggung kelinci dibagi menjadi Empat bagian berbentuk bujur sangkar ditandai dengan spidol. Area punggung dianastesi menggunakan etil klorida spray selanjutnya dibuat luka eksisi pada masing-masing area dengan ukuran panjan $3 \mathrm{~cm}$ dan kedalaman o,3 cm(Ramdani, Mambo, and Wuisan 2014).

2) Pembagian kelompok uji dan pengamatan Pengujian dibagi menjadi empat kelompok sebagai berikut:

Kelompok 1 : Luka di beri formula optimum gel serbuk daging limbah tomat Kelompok 2 : luka diberi betadin salap 10\%

Kelompok 3

Kelompok 4

: Luka diberi basis gel

apa-apa
Dzun Haryadi Ittiqo, Optimasi Formula Gel... 22

Masing-masing kelompok di replikasi 3 kali, area luka di olesi sampel uji 3 kali sehari selama 8 hari. Pengamatan dilakukan dengan mengukur panjang luka selama perlakuan.

\section{Analisis Data}

Analisis data dengan pendekatan D-Optimal menggunakan Design Expert versi 7.1.5 .dan Untuk mengetahui perbedaan antar kelompok perlakuan dilakukan analisis dengan program SPSS 16.0 dengan taraf kepercayaan 95\%.

\section{HASIL DAN PEMBAHASAN}

\section{Pembuatan Ekstrak}

Limbah daging buah tomat dibersihkan dan dilakukan perajangan, timbang 900 gram selanjutnya di lakukan pengeringan di dalam oven pada suhu 60$80^{\circ} \mathrm{C}$ sampai kering (Goeswin 2007). Simplisia kering dihaluskan dengan blender selama 10 menit, selanjutnya di ayak dengan mesh no 6o sehingga didapatkan serbuk yang halus sebanyak 28,69 gram, dengan rendemen 3,13\%. Berdasarkan Materia Medika Indonesia Jilid I, persyaratan kadar air adalah kurang dari 10,00 \% (DEPKES 2009). Mikroorganisme sangat mudah berkembang biak dalam media air, maka kadar air yang kecil dalam serbuk meminimalkan kontaminan oleh mikroorganisme.

\section{Pembuatan Gel}

Sediaan gel di buat menggunakan basis Natrium Karboksimetil selulosa (Na-CMC) dengan tambahan gliserin dan propilenglikol. Pemilihan Basis Na-CMC untuk mendapatkan gel yang jernih, bersifat netral dan memiliki daya pengikat zat aktif yang kuat karena Na- CMC merupakan polimer yang berasal dari turunan selulosa yang akan cepat mengembang dalam air panas dan membentuk campuran jernih yang bersifat netral. Pada pembuatan gel ditambahkan gliserin dan propilenglikol. Gliserin dan propilenglikol bekerja sebagai humektan atau penahan lembab yang berfungsi meningkatkan kelembutan dan daya sebar sediaan serta melindungi dari kemungkinan menjadi kering.

\section{Desain Formula Gel Serbuk Daging Limbah Tomat (Licopersicum asculentum Mill) dengan Design Expert 7.1.5.}

Optimasi formula krim menggunakan metode design optimal. Nilai persentase terendah sampai tertinggi dari masing-masing pembawa dapat dilihat pada tabel 1;

\section{Tabel 1.}

Persentase aras bawah dan atas pembawa Gel Serbuk Daging Limbah Tomat (Licopersicum asculentum Mill)

\begin{tabular}{cccc}
\hline \multicolumn{3}{c}{$\begin{array}{c}\text { Persentase Aras Bawah dan Aras Atas } \\
\text { Masing-masing Pemawa }\end{array}$} \\
\hline \multicolumn{2}{c}{ CMC-Na (\%) } & \multicolumn{2}{c}{ Propilenglikol (\%) } \\
\hline Rendah & tinggi & Rendah & tinggi \\
\hline 5 & 6 & 4 & 5 \\
\hline
\end{tabular}

Persentase tersebut sebagai acuan yang digunakan dalam pembuatan formula optimum menggunakan design expert 7.1.5. Dari data yang 
dimasukkan kedalam desain didapatkan 13 formula dengan 3 respon yaitu daya sebar, dan daya lekat dapat dilihat pada tabel 2.
Masing-masing formula dibuat sejumlah 25 gram dengan komposisi yang mengandung $\mathrm{CMC}-\mathrm{Na}$, Propilenglikol, giliserin dan Aquadest, ditambahkan serbuk daging limbah tomat sebanyak $1,25 \mathrm{~g}$.

\begin{tabular}{|c|c|c|c|c|}
\hline \multirow[t]{3}{*}{ RUN } & \multicolumn{2}{|c|}{ BAHAN TEROPTIMASI (\%) } & \multicolumn{2}{|c|}{ RESPON } \\
\hline & $\mathrm{CMC}-\mathrm{Na}$ & Propilen glikol & Daya Sebar & Daya lekat \\
\hline & & & Diameter rata-rata $(\mathrm{cm})$ & (Detik) \\
\hline $\mathbf{1}$ & 6 & 4 & 2.7 & 9 \\
\hline 2 & 5 & 5 & 3.5 & 10 \\
\hline 3 & 5 & 5 & 5 & 1 \\
\hline 4 & 5 & 5 & 3.5 & 1 \\
\hline 5 & 6 & 4 & 2.6 & 28 \\
\hline 6 & 6 & 4 & 3 & 37 \\
\hline 7 & 6 & 4 & 3.1 & 25 \\
\hline 8 & 6 & 4 & 2.9 & 37 \\
\hline 9 & 5 & 5 & 3.2 & 38 \\
\hline 10 & 5 & 5 & 2.9 & 21 \\
\hline $\mathbf{1 1}$ & 5 & 5 & 3 & 6 \\
\hline 12 & 5 & 5 & 2.9 & 14 \\
\hline 13 & 6 & 4 & 2.8 & 16 \\
\hline
\end{tabular}

Dari tabel di atas dibuat 13 formula dengan dua respon yaitu daya sebar dan Daya lekat. Setelah dibuat 13 formula dan kedua respon di uji maka didapatkan hasil yang kemudian dimasukkan dalam tabel respon seperti yang terlihat pada tabel 2. Dari percobaan formula gel serbuk daging limbah tomat yang dihasilkan di analisis dengan design expert 7.1.5 dengan penjabaran analisis yang dihasilkan sebagai berikut :

\section{a. Hasil Daya Sebar}

Daya sebar merupakan parameter penting dalam penilaian kemampuan gel untuk menyebar. Sediaan gel dapat dikatakan memenuhi sifat mekanik yang optimal, jika sediaan mudah dikeluarkan dari wadah dan memiliki daya sebar yang baik pada kulit ketika sediaan diaplikasikan sehingga dapat memberikan kenyamanan penggunaan oleh konsumen (Garg et al. 2002). Daya sebar gel diperlihatkan oleh diameter dan luas sebar gel terhadap beban yang ditambahkan. Spesifikasi diameter daya sebar yaitu $5-7 \mathrm{~cm}$ (Garg et al. 2002).

Tabel 3.

Hasil analisis statistik ANOVA respon daya sebar

\begin{tabular}{ccc}
\hline Source & p-value & Kemaknaan \\
\hline $\begin{array}{c}\text { Model (Linier } \\
\text { mixtur) }\end{array}$ & 0,0440 & Signifikan \\
\hline
\end{tabular}

Lack offit test $\quad 0,9830 \quad$ Tidak signifikan

Berdasarkan hasil analisis ANOVA pada tabel 3, diketahui bahwa model Linier mixtur merupakan model yang tepat dalam menerangkan respon daya sebar gel, hal ini terlihat dari nilai pvalue yaitu $0,0440(<0,05)$ menunjukkan hasil yang signifikan. Hasil Lack of fit yang diperoleh sebesar $0,9830(>0,05)$ yang berarti tidak ada perbedaan bermakna antara data observasi dengan data prediksi model yang dibuat. Hasil pengujian daya sebar kemudiaan dianalisis menggunakan Design Expert 7.1.5 untuk melihat pengaruh masing-masing komponen ataupun interaksi antar komponen terhadap daya sebar yang dihasilkan.

Persamaan D-optimal Design (pseudo components) yang diperoleh adalah persamaan linear yang dapat dilihat pada persamaan (1).

$\mathrm{Y}=5,54 \mathrm{~A}+10,76 \mathrm{~B}$.

Keterangan :

$\mathrm{Y}=$ Daya Sebar

$\mathrm{A}=$ Komposisi CMC-Na

$\mathrm{B}=$ Komposisi Propilenglikol

Pengaruh positif (meningkatkan daya sebar) diberikan oleh kedua komponen CMC-Na (A), Propilenglikol (B), sehingga campuran kedua komponen tersebut disimpulkan dapat meningkatkan daya sebar gel.

b. Hasil Daya lekat

Daya lekat sediaan gel menggambarkan lama kontak antara gel dengan kulit dan kenyamanan pengguna. Gel yang baik mampu menjamin waktu kontak yang efektif dengan kulit 
dan tidak terlalu lengket sehingga tujuan penggunaannya tercapai. Respon daya lekat 13 sampai 38 detik, waktu lekat mempengaruhi efektivitas kerja zat aktif di area pemberian, semakin lama gel melekat pada kulit maka diharapkan semakin mempercepat penyembuhan luka. Daya lekat diuji normalitasnya menggunakan Desgin Expert 7.1.5.Analisis kurva normal plot of residual menunjukkan bahwa data terdistribusi normal, sehingga dapat dilanjutkan uji ANOVA maka didapatkan hasil statistik yang dapat dilihat pada tabel 4 .

Tabel 4.

Hasil analisis statistik ANOVA respon daya lekat Source p-value Kemaknaan

\begin{tabular}{ccc} 
Model (Linier mixtur) & 0,0488 & Signifikan \\
\hline Lack of fit test & 0,9250 & Tidak signifikan
\end{tabular}

Berdasarkan hasil analisis ANOVA pada tabel 4, diketahui bahwa model Linier mixtur merupakan model yang tepat dalam menerangkan respon daya lekat gel, hal ini terlihat dari nilai p-value yaituo,0488 $(<0,05)$ menunjukkan hasil yang signifikan. Hasil Lack of fit yang diperoleh sebesar 0,9250 $(>0,05)$ yang berarti tidak ada perbedaan bermakna antara data observasi dengan data prediksi model yang dibuat . Hasil pengujian daya lekat kemudiaan dianalisis menggunakan Design Expert 7.1.5 untuk melihat pengaruh masingmasing komponen ataupun interaksi antar komponen terhadap daya lekat yang dihasilkan. Persamaan D-optimal Design (pseudo components) yang diperoleh adalah persamaan linear yang dapat dilihat pada persamaan (2). $\mathrm{Y}=27,84 \mathrm{~A}+9,19 \mathrm{~B}$
Keterangan :

$\mathrm{Y}=$ Daya Lekat

$\mathrm{A}=$ Komposisi CMC-Na

$\mathrm{B}=$ Komposisi Propilenglikol

Pengaruh positif (meningkatkan daya lekat) diberikan oleh kedua komponen CMC-Na (A), Propilenglikol (B), sehingga campuran kedua komponen tersebut disimpulkan dapat meningkatkan daya lekat gel.

\section{Optimasi dan Verifikasi Formula Optimal Gel Serbuk Daging Limbah Tomat (Licopersicum asculentum Mill)}

Proses optimasi bertujuan untuk mendapatkan rekomendasi beberapa formula baru yang optimal menurut design, formula paling optimal adalah formula dengan nilai desirability maksimum. Desirability yang semakin mendekati nilai 1,0 menunjukkan kemampuan design menghasilkan formula yang mendekati sempurna(Nurmiah et al. 2013). Komponen formula gel yang dioptimasi adalah CMC-Na dan Propilenglikol, respon yang digunakan adalah uji daya sebar dan Uji daya lekat. Setiap komponen dan respon dilakukan pembobotan kepentingan untuk memperoleh respon optimal yang diinginkan. Pembobotan kepentingan ini disebut juga importance, dimana terdapat pilihan tanda positif satu $(+)$ hingga positif lima $(+++++)$. Semakin tinggi tingkat kepentingan dari komponen dan respon yang diukur, maka semakin besar bobot kepentingan yang diberikan. Formula yang disarankan Design Expert 7.1.5 sebanyak satu (1) solusi formula yang terlihat pada tabel 6 .

Tabel 6.

Solusi formula optimal krim berdasarkan Design Expert 7.1.5

\begin{tabular}{ccccc} 
CMC-Na (\%) & Propilenglikol (\%) & Daya Sebar (Luas) & $\begin{array}{c}\text { Daya Lekat } \\
\text { (detik) }\end{array}$ & Decirability \\
\hline $\mathbf{5 , 5 0}$ & 4,50 & 8,15 & 18,51 & 0,97 \\
\hline
\end{tabular}

Nilai desirability dari formula optimal sebesar 0,97 yang artinya formula tersebut akan menghasilkan karakteristik paling optimal dan sesuai dengan keinginan peneliti sebesar $97 \%$.
Pembuktian komponen terprediksi dengan melakukan percobaan sebanyak tiga kali replikasi, hasil perbandingan prediksi dengan observasi dapat dilihat pada tabel 7 .

Tabel 7.

Prediksi dan hasil verifikasi respon formula optimal

\begin{tabular}{|c|c|c|c|c|c|c|}
\hline \multirow[t]{2}{*}{ Respon } & \multirow[t]{2}{*}{ Prediksi } & \multirow[t]{2}{*}{ Obsevasi } & \multicolumn{2}{|c|}{$95 \%$ CI } & \multicolumn{2}{|c|}{ 95\% PI } \\
\hline & & & Low & High & Low & High \\
\hline \multirow[t]{3}{*}{ Daya Sebar } & \multirow[t]{3}{*}{$8,15 \mathrm{~cm}$} & 3.7 & \multirow[t]{3}{*}{6.2} & \multirow[t]{3}{*}{10.1} & \multirow[t]{3}{*}{0.9} & \multirow[t]{3}{*}{15.4} \\
\hline & & 4.4 & & & & \\
\hline & & 4.3 & & & & \\
\hline Rata-rata \pm SD & & $4.1 \pm 0.4$ & & & & \\
\hline \multirow[t]{3}{*}{ Daya Lekat } & \multirow[t]{3}{*}{$18,51 \mathrm{dtk}$} & 10.6 & \multirow[t]{3}{*}{11.4} & \multirow[t]{4}{*}{$25 \cdot 6$} & \multirow[t]{3}{*}{-8.1} & \multirow[t]{4}{*}{45.1} \\
\hline & & 15 & & & & \\
\hline & & 12.9 & & & & \\
\hline Rata-rata \pm SD & & $12.8 \pm 2.2$ & & & & \\
\hline
\end{tabular}


Point prediction pada program Design Expert 7.1.5 dapat memperkirakan nilai respon dan nilai observasi dengan taraf kepercayaan 95\%. Proses verifikasi ini dilakukan dengan melihat nilai hasil observasi berada pada rentang Confidence Interval (CI) dan prediction interval (PI). Makna dari 95\% CI adalah rentang nilai rata-rata hasil observasi pada taraf kepercayaan 95\%, sedangkan 95\% PI (prediction interval) adalah rentang nilai prediksi individu hasil observasi pada taraf kepercayaan 95\% (Engelen, Sugiyono, and Budijanto 2015)

Hasil respon observasi Daya sebar sebesar 3,7 cm; $4,4 \mathrm{~cm}$ dan $4,3 \mathrm{~cm}$, dengan rata-rata dan standar deviation 4,1 $\pm 0,4$. Hasil masing-masing nilai individu dari tiga kali replikasi masuk pada rentang PI 95\% yaitu antara 0,9 - 15,4. Hasil respon observasi daya lekat sebesar 10,6 detik, 15 detik dan 12,9 detik dengan rata- rata dan standar deviation $12,8 \pm 2,2$. Nilai masingmasing individu dari tiga kali replikasi masuk pada rentang PI 95\% yaitu antara -8,1- 45,1 dan niali rata rata masuk pada rentang CI 95\% yaitu antara 11,4 - 25,6. Hasil verifikasi nilai observasi masuk pada rentang nilai prediksi mengindikasikan kesesuaian model yang ditentukan oleh Design Expert 7.1.5.

\section{Analisis Aktivitas Lama Penyembuhan Luka Eksisi Pada Kelinci}

Pengukuran efek penyembuhan luka dilakukan berdasarkan profil penurunan panjang luka yang ditandai dengan terbentuknya keropeng yang menutupi luka. Profil penyembuhan luka dari keempat perlakuan dapat dilihat pada gambar 1.

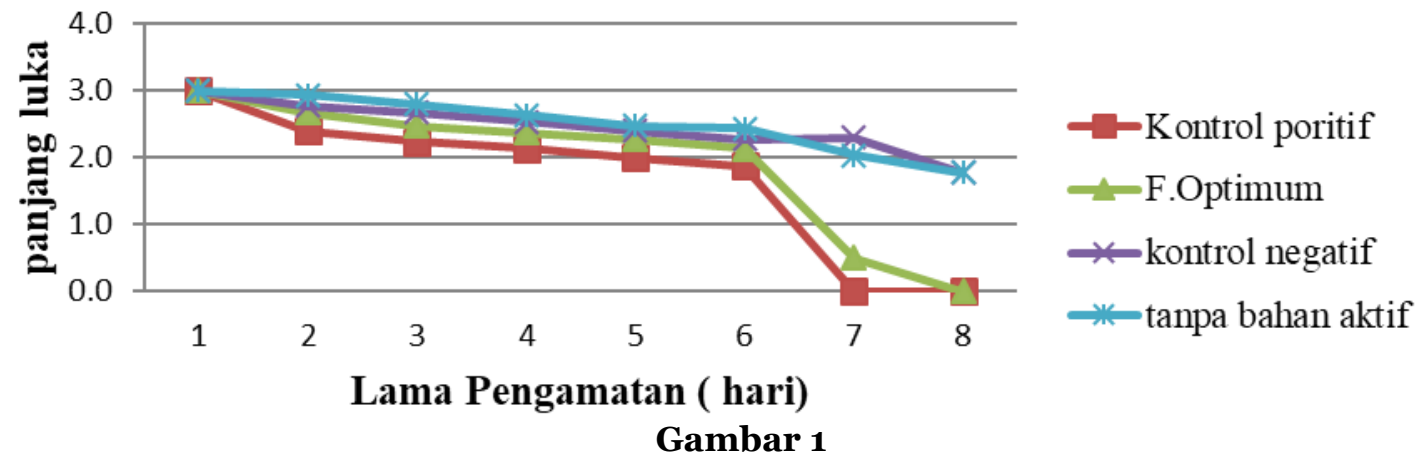

Profil penyembuhan luka dari keempat perlakuan

Profil penurunan panjang luka menggambarkan ada perbedaan antara kelompok perlakuan. Formula optimum gel menunjukkan penurunan yang sama dengan kontrol positif ( betadin zalp
10\%). Untuk mengetahui sejauh mana perbedaan antar kelompok perlakuan selanjutnya dilakukan analisis dengan program SPSS 16.0 dengan taraf kepercayaan 95\%, hasil analisis dapat dilihat pada tabel

Tabel 8.

Hasil analisis SPSS 16.0 kelompok uji perlakuan Multiple Comparisons

\begin{tabular}{|c|c|c|c|c|c|c|}
\hline \multicolumn{7}{|c|}{ Dependent Variable : panjang_luka } \\
\hline & \multirow[t]{2}{*}{ (I) kelompok } & \multirow{2}{*}{$\begin{array}{c}(\mathrm{J}) \\
\text { kelompok }\end{array}$} & \multirow[t]{2}{*}{ Std. Error } & \multirow[t]{2}{*}{ Sig. } & \multicolumn{2}{|c|}{ 95\% Confidence Interval } \\
\hline & & & & & $\begin{array}{l}\text { Lower } \\
\text { Bound }\end{array}$ & Upper Bound \\
\hline \multirow[t]{9}{*}{ LSD } & \multirow[t]{3}{*}{ kontrol positif } & $\begin{array}{c}\text { kontrol } \\
\text { negatif }\end{array}$ & 0.226 & 0.002 & -1.182 & -0.285 \\
\hline & & $\begin{array}{c}\text { tanpa bahan } \\
\text { uji }\end{array}$ & 0.226 & 0.001 & -1.228 & -0.331 \\
\hline & & formula & 0.226 & 0.388 & -0.645 & 0.253 \\
\hline & \multirow[t]{2}{*}{$\begin{array}{c}\text { kontrol } \\
\text { negatif }\end{array}$} & $\begin{array}{l}\text { kontrol } \\
\text { positif }\end{array}$ & 0.226 & 0.002 & 0.285 & 1.182 \\
\hline & & formula & 0.226 & 0.019 & 0.089 & 0.986 \\
\hline & \multirow[t]{3}{*}{$\begin{array}{l}\text { tanpa bahan } \\
\text { uji (basis gel) }\end{array}$} & $\begin{array}{l}\text { kontrol } \\
\text { positif }\end{array}$ & 0.226 & 0.001 & 0.331 & 1.228 \\
\hline & & $\begin{array}{l}\text { kontrol } \\
\text { negatif }\end{array}$ & 0.226 & 0.84 & -0.403 & 0.495 \\
\hline & & formula & 0.226 & 0.011 & 0.135 & 1.032 \\
\hline & $\begin{array}{l}\text { Formula } \\
\text { optimum }\end{array}$ & $\begin{array}{l}\text { kontrol } \\
\text { positif }\end{array}$ & 0.226 & 0.388 & -0.253 & 0.645 \\
\hline
\end{tabular}


Dzun Haryadi Ittiqo, Optimasi Formula Gel... 26

\begin{tabular}{ccccc}
$\begin{array}{c}\text { kontrol } \\
\text { negatif }\end{array}$ & 0.226 & 0.019 & -0.986 & -0.089 \\
\hline $\begin{array}{c}\text { tanpa bahan } \\
\text { uji }\end{array}$ & 0.226 & 0.011 & -1.032 & -0.135 \\
\hline
\end{tabular}

Pada tabel 8, menunjukkan kelompok kontrol positif dibandingkan dengan kontrol negativ dan tanpa bahan uji (basis gel) menunjukkan perbedaan yang signifikan tetapi dibandingkan dengan formula optimum tidak menunjukkan perbedaan yang bermakna, artinya kemampuan formula optimum dalam menyembuhkan luka sama dengan kontrol positif. Kelompok kontrol negativ di bandingkan dengan kontrol positif dan formula oftimum tetap menunjukkan perbedaan yang signifikan. Kelompok tanpa bahan uji (basis gel) dibandingkan dengan kontrol positif menunjukkan perbedaan yang bermakna tetapi dengan kontrol negativ tidak menunjukkan perbedaan. Kelompok formula optimum dibandingkan dengan kontrol positif tidak berbeda bermakna sedangkan dengan kontrol negativ dan tanpa bahan uji (basis gel) berbeda bermakna.

Untuk mengetahui kemampuan masing-masing kelompok dalam menurunkan panjang luka dapat dideskripsikan oleh nilai mean $\pm \mathrm{SD}$. Kontrol positif $1,729 \pm 1,021$; formula oftimum $1,925 \pm 1,033$; kontrol negative 2,463 $\pm 0,381$; tanpa bahan uji $2,508 \pm 0,440$. Nilai mean yang lebih kecil menunjukkan penurunan panjang luka yang lebih cepat, artinya kelompok kontrol positif dan formula oftimum lebih efektif dalam menurunkan panjang luka bila dibandingkan dengan kontrol negativ dan tanpa bahan uji.

\section{KESIMPULAN DAN SARAN}

1. Kesimpulan

Hasil optimasi formula gel menggunakan Design expert 7.1.5 didapatkan Persentase perbandingan penyusun gel yang optimal yaitu $\mathrm{CMC}-\mathrm{Na}$ dan Propilenglokol masing-masing adalah $5,50 \%$, dan 4,50\%. dengan respon daya sebar $8,15 \mathrm{~cm} 2$, dan Daya lekat 18,51 detik.

b. Formula optimal gel serbuk daging limbah tomat (Licopersicum asculentum Mill) menunjukkan aktivitas penyembuhan luka yang sama dengan betadin zalp $10 \%$, dengan nilai mean \pm SD masing-masing $1,925 \pm 1,033$ dan 1,729 $\pm 1,021$.

2. Saran

Perlu dilakukan uji stabilitas dan uji iritasi sediaan gel formula optimum serbuk daging limbah tomat (Licopersicum asculentum Mill).

\section{DAFTAR PUSTAKA}

[1]. Aponno, Jeanly V. 2014. "Uji Efektivitas Sediaan Gel Ekstrak Etanol Daun Jambu Biji (Psidium Guajava Linn) Terhadap Penyembuhan Luka Yang Terinfeksi Bakteri Staphylococcus Aureus Pada Kelinci (Orytolagus Cuniculus)." PHARMACON 3.

[2]. Chaudhary, Hema, Kanchan Kohli, Saima Amin, Permender Rathee, and Vikash Kumar. 2011. "Optimization and Formulation Design of Gels of Diclofenac and Curcumin for Transdermal Drug
Delivery by Box-Behnken Statistical Design.” Journal of Pharmaceutical Sciences 100(2):580-93.

[3]. DEPKES, RI. 2009. Materia Medika Indonesia. 1st ed. Jakarta.

[4]. Engelen, Adnan, Sugiyono, and Slamet Budijanto. 2015. "Optimasi Proses Dan Formula Pada Pengolahan Mi Sagu Kering.” 35.

[5]. Garg, Alka, Deepika Aggarwal, Sanjay Garg, and Anil K. Singla. 2002. "Spreading of Semisolid Formulations." Pharmaceutical Technology (September):84-105. Retrieved Goeswin, A. 2007. Teknologi Bahan Alam. Bandung: ITB.

[6]. Kurniawati, Linda, Indri Hapsari, and Dwi Hartanti. 2010. "Daya Repelan Gel Minyak Atsiri Bunga Kenanga (Cananga Odorata (Lmk) Hook.f \& Thoms) Dalam Basis Carbopol, Terhadap Nyamuk Aedes Aegypti Linda." Pp. 38-49 in, vol. 7. Retrieved

[7]. Nurmiah, Sitti, Rizal Syarief, Rosmawaty Peranginangin, and Budi Nurtama. 2013. "Aplikasi Response Surface Methodology Pada Optimalisasi Kondisi Proses Pengolahan Alkali Treated Cottonii ( ATC ) Process Conditions Of Alkali Treated Cottonii ( ATC ) Processing." 9-22.

[8]. Priyandari, Yeni and Siti Arfina Titi Maulidah. 2015. "Getah Pohon Jarak (Jatropha Curcas) Topical Mempercepat Lama Penyembuhan Luka Eksisi Mencit (Effect Of Jarak Tree Topical Increase Wound Healing Excision Period Of Mice).” Journals of Ners Community 6.

[9]. Purwanto, Purwanto, Mufrod Mufrod, and Alissya Swastika NSP. 2015. "Antioxidant Activity Of Cream Dosage Form Of Tomato Extract (Solanum Lycopersicum L.)." Traditional Medicine Journal 18(3):132-140.

[10]. Ramdani, Nurul Fitri, Christi Mambo, and Jane Wuisan. 2014. "Uji Efek Daun Kemangi ( Ocimum Basilicum L .) Terhadap Penyembuhan Luka Insisi Pada Kelinci ( Oryctolagus Cuniculus ).”

[11]. Sjamsu, hidayat. 2005. Buku Ajar Ilmu Bedah,EGC. Jakarta.

[12]. Soebagio, Boesro and Taofik Rusdiana. 2007. "Pembuatan Gel Dengan Aqupec HV-505 Dari Ekstrak Umbi Bawang Merah (Allium Cepa, L.) Sebagai Antioksidan.” Abstrak

[13]. Suhartati, Rochmanah. 2015. "Potensi Antibakteri Limbah Tomat (Lycopersicum Esculentum Mill) Terhadap Bakteri Staphylococcus Aureus." Jurnal Kesehatan Bakti Tunas Husada 13.

[14]. Sumardiono, Siswo, Mohamad Basri, and Rony Pasonang Sihombing. 2009. "Analisis Sifat-Sifat Psiko-Kimia Buah Tomat (Lycopersicon Esculentum) Jenis Tomat Apel, Guna Peningkatan Nilai Fungsi Buah Tomat Sebagai Komoditi Pangan Lokal."

[15].Swastika, ANSP and Purwanto Mufrod. 2013. "Antioxidant Activity of Cream Dosage Form of Tomato Extract (Solanum Lycopersicum L.).” Journal Tradicional Medical 18(3):132-140. 